\title{
Participation in OER Creation: A Trajectory of Values
}

\author{
Erin Meger \\ Department of Computer Science \\ Wilfrid Laurier University \\ Michelle Schwartz \\ Centre for Excellence in Learning and \\ Teaching, Ryerson University \\ Wendy Freeman \\ Centre for Excellence in Learning and \\ Teaching, Ryerson University
}

\section{Correspondence: \\ Erin Meger \\ Department of Computer Science \\ Wilfrid Laurier University \\ Email: ekmmeger [at] wlu.ca}

\begin{abstract}
This paper provides an analysis of interviews with seven faculty members who engaged in creating Open textbooks funded by government grants at a university in Canada in 2018. Using four valuesaccess and equity, community and connection, agency and ownership, and risk and responsibility_identified by Sinkinson (2018), McAndrew (2018), and Keyek-Fransen (2018), we traced the ways in which university faculty members' understanding of Open changed through the process of Open Educational Resource creation. As a teaching support-focused unit, we explore ways to provide our faculty and instructors with meaningful opportunities to develop their Open pedagogy. These findings reconceive the way that Open Educational Practice can be promoted at our University and others. Instead of focusing solely on OER creation, our faculty started engaging in thinking through the different conceptions of Open educational practice and identifying which concepts resonated with them. By reframing the ways in which faculty thought about Open Educational Practices, we have been better able to address the ways in which we support them.
\end{abstract}

Keywords: open pedagogy, open educational practice, open educational resources, open education 


\section{Introduction}

Why do faculty decide to create Open Educational Resources? What motivates them to invest time and energy into the creation process? What values do they hold in relation to Open pedagogy, and how do those values change over time? These are the questions we explored with a group of faculty who engaged in creating Open Educational Resources with the goal of better understanding the shift from Open as an element of a teaching resource to Open as an approach to pedagogy.

In a series of three blog posts, Sinkinson (2018), McAndrew (2018), and Keyek-Fransen (2018) proposed four values associated with Open pedagogy: access and equity, agency and ownership, community and connection, and risk and responsibility. Coming from research conducted in 2018, this article offers an analysis of interviews conducted with seven faculty members who engaged in creating Open textbooks at a Canadian university. The interviews have been published as stories in the Ryerson Open Moments collection (Meger et al., 2020), and the analysis presented below is novel. Using the four values identified by Sinkinson, McAndrew, and Keyek-Franson, we traced the ways in which university faculty members' understanding of Open changed through the process of Open Educational Resource (OER) creation. Respondents reported a range of reasons for developing Open textbooks; our analysis suggests that through the process of OER creation and through learning about Open licensing, they encountered changes in their understanding of pedagogical practice in relation to Openness.

As a teaching support-focused unit, we are always exploring how we can provide our faculty and instructors with meaningful opportunities to develop their understanding of Open pedagogy. Our goal was to use our analysis of these shifts to help us improve the ways in which we promote and support Open education and Open pedagogy within universities. Our experiences supporting educators in adopting and creating OER led us to want to learn more about how the understanding of pedagogy develops as a result of participating in the creation of OER.

This research explores the shift in values as understood by educators adopting Open, from creation of a resource through to utilization of the resource and their journey therein. This study was guided by the question, in what ways do educators value Open in their teaching, and do educators shift their understanding when learning more about the Open Educational Resource creation process?

\section{Literature}

The evolution of the definition of Open Educational Practice (OEP) is closely intertwined with the creation and use of OER. Pitt et al. (2020), noted that Wiley (2014) suggested that the use of OER is a pre-condition for developing and adopting Open Educational Practice. There are many different approaches to defining Open pedagogy. Definitions that privilege access tend to focus on the adoption or creation of Open Educational Resources (Cronin, 2017). Open, in this context, is focused on the licensing, adoption, and potential re-use of resources such as textbooks. Czerniewicz et al. (2017) suggested that this narrows the focus of Open to the legal aspects of Openness. Beetham et al. (2012) advocated for a broader definition of Open Educational Practices that overlaps with the creation of OER. Specifically, they promoted an explanation that implicates practices that include sharing and collaboration, making knowledge publicly accessible, and expanding teaching and learning to Open networks. In our interviews with participants, we explored the changing dimensions of the meaning of Open for faculty engaged in OER creation. 
To begin thinking through a framework for our analysis, we first turned toward DeRosa and Jhangiani's (n.d.) work in the Open Pedagogy Notebook. In it, they suggested asking a series of questions as you begin a journey towards Open Educational Practice: "What are your hopes for...higher education? ... How do you see the roles of the learner and the teacher? What challenges do your students face... and how does your pedagogy address them?" (DeRosa \& Jhangiani, n.d., para. 1). In their presentation at the 2016 Open Education Conference, they explained that "Communities (not just content), Learner-Driven Education (not just assignments), Access (not just textbooks), and Public Contexts (not just preparation)" were the four components of Open pedagogy (DeRosa \& Jhangiani, 2016, slide 5).

\section{Conceptual Framework}

Sinkinson (2018), McAndrew (2018), and Keyek-Franssen (2018), reflecting on their experience of Open Educational Practice as well as the further examination of definitions of Open pedagogy, articulated a framework that identified "the aspects of open pedagogy that most strongly resonate with us and our teaching values," including Access and Equity, Agency and Ownership, Community and Connection, and Risk and Responsibility (Sinkinson, 2018, para. 5).

Sinkinson (2018) framed these aspects of Open educational practice as commitments made by educators to their students, as described in Table 1.

\section{Table 1}

Values and Commitments of OEP

\begin{tabular}{ll}
\hline \multicolumn{1}{c}{ Value } & \multicolumn{1}{c}{ Commitment } \\
\hline Access and Equity & $\begin{array}{l}\text { Reducing barriers that prevent equitable access to education, including } \\
\text { economic, technical, social, cultural, and political factors. }\end{array}$ \\
$\begin{array}{l}\text { Community and } \\
\text { Connection }\end{array}$ & $\begin{array}{l}\text { Facilitating connections across the boundaries of learning experiences, } \\
\text { classrooms, campuses, countries, communities, and viewpoints. }\end{array}$ \\
$\begin{array}{l}\text { Agency and } \\
\text { Ownership }\end{array}$ & $\begin{array}{l}\text { Protecting agency and ownership of one's own learning experiences, } \\
\text { choices of expression, and degrees of participation. }\end{array}$ \\
$\begin{array}{l}\text { Risk and } \\
\text { Responsibility }\end{array}$ & $\begin{array}{l}\text { Interrogating tools and practices that mediate learning, knowledge } \\
\text { building, and sharing, and resisting the treatment of open as neutral. }\end{array}$
\end{tabular}

Note: Commitments quoted from Sinkinson, 2018, paras. 6-9.

By making these commitments to their students, Sinkinson, McAndrew, and Keyek-Franssen believed that students can be supported in developing the valuable habits of responsibility, curiosity, empathy, and participation. In our analysis, we focused specifically on the values of Open Educational Practice as reported by our participants. 
As was mentioned in the literature review, the conceptual roots of Open Educational Practice began with a heavy focus in creating digital and accessible materials that were available to students at little-to-no cost, and this initial starting point of the field of Open has strong connections to the value of equity and access (Bali, 2017; Lambert, 2018). This is the commitment to reducing barriers that prevent equitable access to education, including economic, technical, social, cultural, and political factors. It embraces educational access, such as degree programs available both geographically and financially. In a blog post, Jhiangiani (2018) discussed the importance of OER in accessible education to highlight "the deepest and most important problems of our times, through an inclusive education for all that serves all" (para. 35). Access extends to the legal understanding of copyright and production that Open educational resources require. Further, there is a component of this value to encourage others to teach and learn in Open networks as well as reusing content in teaching and other contexts.

We were especially interested in exploring the value of access and equity. While open education has traditionally been situated within a larger frame of social justice in education, it has also more recently shifted into the mainstream, and with that increased popularity "has also been subjected to 'openwashing' by market forces" (Lambert \& Czerniewicz, 2020, para. 2)

The next value identified by Sinkinson, McAndrew, and Keyek-Franssen is community and connection, which is a "commitment to facilitating connections across the boundaries of learning experience, classrooms, campus, countries, communities, and viewpoints" (Sinkinson, 2018, para. 7). In this value there is the potential for shared knowledge networks, collaborative and networked participation, the union of disparate learning spaces, and the creation of dialogue between all players in the educational process. Open education should "embrace collaborative knowledge creating participation educational models and experiential practices, mentoring and apprentices," according to Corney (2006; as cited in Cronin, n.d., para. 9).

As a value, agency and ownership is defined as the "commitment to protecting agency and ownership of one's own learning experiences, choices of expression, and degrees of participation" (Sinkinson, 2018, para. 8). This is a key value for Open Educational Practice because agency and ownership empower learners to co-create knowledge, encourages collaboration between students and faculty, and facilitates learners playing key roles in the creation of OER. Creative Commons licensing provides content creators with the ability to choose the ownership level that feels the most comfortable.

These licenses offer is a spectrum of intellectual property rights that allow lecturers to offer their work to others under certain specified conditions, starting from the most restrictive license that allows others to copy, distribute, display and perform copyrighted work to the most accommodating license which allows others to copy, distribute, remix and extend the original work - even commercially - as long as the original author is acknowledged. (Hodgkinson-Williams \& Gray, 2009, p. 109)

The final value is risk and responsibility, which is defined as the "commitment to interrogate tools and practices that mediate learning, knowledge building, and sharing and to resist the treatment of open as neutral" (Sinkinson, 2018, para. 9). This value encourages Open education practitioners to think critically about their approach to Open education. Hodgkinson-Williams (2010) discussed Archer's theory of active agents as a method to which instructors may choose to partake in OER. They noted that "Being an 'active agent' hinges on the fact that individuals develop and define their ultimate concerns, those internal goods that they care about most and ... [seek] to develop a course(s) of action to realize that concern by elaborating a project" (Archer 2007, as cited in Hodgkinson-Williams, 2010, p. 7). 


\section{Method}

This study took place at Ryerson University (as it was known at the time). Between 2016 and 2019 , faculty engaged in funded OER creation projects, with support from instructional designers, librarians, and educational developers. For these faculty, their concept of Open education was shaped by these OER projects. As such, their experiences have provided us with insight into how faculty members' understanding of Open Educational Practice can change over time through engaging with OER creation. Our initial goal was to capture descriptions of their stories that could be shared with others to help promote OER on campus; however, through interviews, we learned about the shifts that occurred in their understanding of Open education over time (Meger et al., 2020).

Prior to participant recruitment, the study was approved by the University's research ethics board. The research team included a librarian, an instructional designer, two staff from the learning and teaching centre, and a graduate student. A list of all faculty known to have created OER projects from 2016 to 2018 were invited to participate in the study. Of the 15 invitations to participate, seven respondents agreed to be interviewed, representing six OER projects. Participants included both sessional and tenured faculty members. All were new to OER when they began their projects, and all projects were completed by the time the interviews took place. The projects represented a range of outputs including Open case studies, textbooks, course packs, videos, and serious games. These faculty members represented a range of disciplines, including business, nursing, and academic writing.

Each participant was interviewed using a semi-structured interview protocol exploring their purpose for getting involved with OER creation, the experiences of the project, the reactions of the students, and the expected and perceived outcomes. Interviews were recorded and transcribed by hand. Participants were provided with the opportunity to review and approve the transcripts.

A thematic analysis of the interview transcripts used the values articulated by Sinkinson (2018), as well as emergent coding to identify unanticipated outcomes from participant narratives. Transcripts were read multiple times separately by each team member, followed by discussion to arrive at the themes representing value reported in the Findings. The focus of this paper is on exploring the trajectory of understanding in relation to the values of Open Education Practice that resulted from participation in OER projects. We were interested in exploring whether engaging in the process of OER creation can lead participants towards values consistent with Open Educational Practice.

\section{Findings}

\section{Access and Equity}

The majority of the instructors interviewed were not aware of OER at the beginning of their journey but had frequently used Open materials such as online journals and articles. One participant remarked, "financial accessibility is as much a mechanism as it is an outcome." Furthermore, many of the participants noted the importance of disability accessibility as well, one noting "that is what Open is supposed to be, available for many different individuals." One instructor had a passion for social justice and was concerned about the cost of learning supplies throughout the degree program in which she taught. This concern brought her to Open

Open/Technology in Education, Society, and Scholarship Association Journal: 2021, Vol. 1(2) 1-10 
education, and she learned that her pedagogy fit well within the concept of Open. Another participant described his pedagogy as an ethos that drives his choices towards Open, reusable, and flexible formats, which later he learned was part of Open. As an understanding of the equity within Openness, he also described the necessity of meeting students at their current level and supporting the students to their fullest potential.

The students who suffer are usually the really good ones, unfortunately, because you end up spending a lot more time with the ones who have more questions, which makes more sense. And so, you end up leaving the ones who are fine on their own on their own, and I don't think that's a good way to push people to their fullest potential.

For another instructor, the pedagogic flexibility of digital and remixable resources allowed further use of scaffolded learning, providing more directed and curriculum-related content to the students. Overall, our participants found that providing course-based content in a variety of modalities that could be remixed and aligned with the needs of their students was beneficial for students of all levels and across all disciplines.

\section{Community and Connection}

Throughout our interviews, the majority of our participants indicated that they began their Open journey with equity in mind, and along the way discovered the benefit of community and connection. Creating Open resources requires the commitment of a community; however, these resources allow further collaboration among students and faculty alike. For one particular instructor, this value is fundamental to her pedagogy. The project of creating a full Open coursework package allowed her to explore the limitations of a digital environment and develop novel techniques of group work and collaboration. She said that "a video is just a video, but an activity and discussion bring that engagement to a new level." This project included detailed activities to be run directly within the classroom community; the learning itself could not be completed without this connection.

Participants indicated that they found that the Open modalities allowed students to collaborate more effectively. Furthermore, the creation of these resources allowed collaboration and community across disciplines to create superior resources. For instance, the game created by one instructor required the expertise of the instructor herself, game designers, instructional designers, and further community testers and graphic designers. All of the resources require a collaborative team and community of instructor creators and facilitate student collaboration and connection in the classroom.

In our analysis, we discovered that instructors moved through this value at some point during their experience regardless of their starting or ending value and the pathway there. For instance, in one project, a faculty member hoped to use the digital modality as a catalyst for free and accessible publications, but noticed this electronic format allowed for much easier collaboration across disciplines. A community of writers and creators was formed, and new connections were built during the creation of the final product. This instructor also collaborated with students across disciplines. This wide variety of understanding and experience allowed the final publication to include a more detailed analysis providing insights across disciplines and experiences than would have been possible otherwise. 
Student collaboration also inspired another faculty member in the English department. Through a flipped classroom, this instructor was able to encourage students to create a learning community amongst themselves, thus encouraging discussion and sharing perspectives.

Sharing perspectives was also a key value that another faculty member had when she explored the gamification of the study of food insecurity: since many of their students come from incredibly diverse backgrounds, the community and collaboration among students is integral to the formation of critical thinkers and future analysis in research.

\section{Agency and Ownership}

As the implementation of OER and OEP continue to develop throughout higher education, the question of ownership of material is a necessary conversation. Many of the instructors we interviewed spent time learning about Creative Commons licensing with librarians and other copyright experts. For one faculty member, the ownership of her intellectual property of the full course she had designed was incredibly important, not only for the credit of her own ideas, but also for future reference towards tenure and promotion.

This value of Agency and Ownership extends beyond just legal matters and other practical considerations. It also speaks to the agency that students have over their own learning and the ownership that students can take over their own learning materials. "We want students to be successful, to get the information quickly, efficiently, and at a low cost," was a key point made by one participant. Another participant remarked that after their project had been implemented, that students were more engaged with the textbook and frequently referred to it on their phones or laptops during group work and activities. Most participants utilized student opinion and student support as they created their Open resources. They found that students who have an opportunity to choose their level of engagement with the material were able to take further agency for their work and their learning.

\section{Risk and Responsibility}

Although many of the participants were thrilled with the opportunity and the learning they had throughout the pedagogical development, the sense of risk was experienced on multiple levels. Creating new modalities and engaging with students in new ways inherently presents risks beyond the time commitment, curriculum design, and student engagement. Each of these risks allows for the avenue of instructors to take responsibility for the work and the design of the final product. Many participants agreed that the new and active learning strategies used within the resources allowed students to take further responsibility for their work.

One faculty member was concerned with the risk of creating free resources with regard to copyright ownership as well as student integrity at other institutions. By creating clear resources, this participant eventually began to embrace the value of community to support learning and a sense of ownership with sufficient licensing. A further risk noted by participants was for adjunct instructors who are not compensated for the work they do in this pedagogical development. Participants further commented that they were only able to do this work after receiving tenure since they no longer needed to focus on receiving research grants and publishing often, creating new opportunities for pedagogical growth. Throughout the process, each faculty member sought out compensation and avenues including Open grants that continue to be more and more readily available. Furthermore, they resoundingly determined that the resources created benefited their students significantly. 


\section{Summary}

We found that most faculty initially approached OER creation through either a lens of "access and equity" or "agency and ownership." However, the process of OER creation led to a more nuanced understanding of Open education as a practice. For example, several faculty members started from a similar place: they wanted to increase access and equity by providing free learning materials for their students. Through the process of creating and using the materials in their teaching, they each moved toward a different value which can be best summarized by one participant: "I find I use Open in a bunch of different places that I hadn't even realized or thought about." One participant felt that an unforeseen benefit of their Open Educational Resource was having more time to provide individualized feedback to students ("community and connection"), another was inspired to get students involved in OER creation ("agency and ownership") and then shared the resources throughout their professional network ("community and connection"). Yet another faculty member felt that in the end they had found a new and exciting way to facilitate learning ("risk and responsibility").

As a teaching support-focused unit, we want to look into ways we can provide our faculty and instructors with meaningful opportunities to develop their Open pedagogy. How can we most effectively foster community and collaboration between faculty, support units, and administration? How can we mitigate the risks that have been identified, so as to create a more equitable university not just for our students, but for our entire community? Having mapped these seven narratives, what struck us most was how the majority of their journeys ended in either "risk and responsibility" or "community and collaboration." These findings have guided our thoughts on supporting Open Educational Practice and will help us set our path moving forward.

\section{Sharing Stories, Promoting Change}

One of our first actions when we completed our interviews was the creation of an Open book from the interviews (Meger et al., 2020). This book was structured around the journey that each faculty member had as they came to Open and then learned from it. We saw this book as a way of providing other faculty at our university with a way to see themselves in Open Educational Practice, and to learn from each other. Each profile included "advice from other faculty," which often reinforced the ways in which faculty members conceived of their work as falling into one of the four values. For instance, one faculty member said, "fail happily as you experiment with Openness and be ready to adjust your course" ("risk and responsibility"), while another revealed, "engage students with your project and listen to their ideas. Students often know what works and what doesn't" ("agency and ownership").

We also used our findings to reconceive the way that we promoted OEP at our University. Instead of focusing solely on OER creation, we started offering a workshop on Open pedagogy that engaged faculty in thinking through the different conceptions of Open Educational Practice and identifying which concepts resonated with them. We found that when prompted, faculty thought more flexibly about Open Educational Practices, and their responses covered all four values from the start. They were also able to identify the support they would need to pursue open educational practices along broader lines.

For instance, participants realized that not only would they need help with things like licensing and copyright permissions for OER creation, which reflects the "access and equity" value, but 
also in "understanding the balance between the incentive for students to participate in creating content and building [the university's] reputation without compensation (i.e., unpaid work)," which connects to the "risk and responsibility" value (Schwartz, n.d., para. 2). Furthermore, the participants were committed to "designing the experience so that the students see it as something engaging, rather than 'work to do' (i.e., discussion board post requirements)," which typifies the "agency and ownership" value (Schwartz, n.d., para. 2). By reframing the ways in which faculty thought about open educational practices, we have been better able to address the ways in which we support them.

\section{Author's Contributions}

This article was produced and written by Michelle Schwartz, Erin Meger, Wendy Freeman through detailed collaborative analysis. The author Michelle Schwartz provided significant writing and conceptualization. The author Erin Meger conducted the interviews and provided detailed writing support. The author Wendy Freeman made significant contributions to writing and analysis.

\section{Open Researcher and Contributor Identifier (ORCID)}

Erin Meger (iD) https://orcid.org/0000-0003-3392-8211

Michelle Schwartz (D) https://orcid.org/0000-0002-3298-4871

Wendy Freeman (D) https://orcid.org/0000-0002-2209-1594

\section{Funding}

The research was funded by a Learning and Teaching grant from the Centre for Excellence in Learning and Teaching at Ryerson University.

\section{Ethics Statement}

The research was approved using the Ryerson Ethics Board approval under item 2018-299.

\section{Conflict of Interest}

The authors do not declare any conflict of interest.

\section{Data Availability Statement}

The original transcripts and audio files are not made available publicly for the privacy of the participants as per the approval by the ethics board.

\section{References}

Bali, M. (2017). April open perspective: What is open pedagogy? Year of Open. https://www.yearofopen.org/april-open-perspective-what-is-open-pedagogy/

Beetham, H., Falconer, I., McGill, L. \& Littlejohn, A. (2012). Open practices: briefing paper. JISC. https://oersynth.pbworks.com/w/page/51668352/OpenPracticesBriefing

Cronin, C. (2017). Openness and praxis: Exploring the use of Open Educational Practices in higher education. The International Review of Research in Open and Distributed Learning, 18(5). https://doi.org/10.19173/irrodl.v18i5.3096

Cronin, C. (2017, April 24). Opening up Open pedagogy. Catherine Cronin. http://catherinecronin.net/research/opening-up-open-pedagogy/ 
Czerniewicz, L., Deacon, A., Glover, M., \& Walji, S. (2017). MOOC-Making and open educational practices. Journal of Computing in Higher Education, 29(1), 81-97. http://hdl.handle.net/10625/56787

DeRosa, R., \& Jhangiani, R. (n.d.). Open Pedagogy. In Open pedagogy notebook. http://openpedagogy.org/open-pedagogy/

DeRosa, R., \& Jhangiani, R. (2016, November 3). Free + freedom: The role of Open pedagogy in the Open Education Movement [Paper presentation]. 2016 Open Education Conference. Richmond, VA. https://www.slideshare.net/thatpsychprof/free-freedom-therole-of-open-pedagogy-in-the-open-education-movement

Hegarty, B. (2015, July-August). Attributes of open pedagogy: A model for using open educational resources. Educational Technology, 55(4), 3-13. https://www.jstor.org/stable/44430383

Hendricks, C. (2017). Navigating open pedagogy, Part 2 - You're the teacher. You're The Teacher. http://blogs.ubc.ca/chendricks/2017/05/23/navigating-open-pedagogy-pt2/

Hodgkinson-Williams, C., \& Gray, E. (2009). Degrees of Openness: The emergence of Open Educational Resources at the University of Cape Town. International Journal of Education and Development Using Information and Communication Technology, 5(5), $101-116$.

https://open.uct.ac.za/bitstream/handle/11427/8860/CHED article OERemergence Hod gkinsonWilliams 2009.pdf?sequence=1

Hodgkinson-Williams, C. (2010). Benefits and challenges of OER for higher education institutions. Commonwealth of Learning. http://hdl.handle.net/11599/3042

Jhangiani, R. (2018, October 5). Open Educational Practices in service of the sustainable development goals. That Psych Prof. https://thatpsychprof.com/open-educationalpractices-in-service-of-the-sustainable-development-goals/

Keyek-Franssen, D. (2018, November 14). 5 tips for supporting inclusive and Open pedagogies. Educause Review. https://er.educause.edu/blogs/2018/11/5-tips-for-supportinginclusive-and-open-pedagogies

Lambert, S., \& Czerniewicz, L. (2020). Approaches to Open Education and social justice research. Journal of Interactive Media in Education, 2020(1). http://doi.org/10.5334/jime.584

McAndrew, A. (2018, November 8). Inclusive and Open pedagogies. Educause Review. https://er.educause.edu/blogs/2018/11/inclusive-and-open-pedagogies

Meger, E., Freeman, W., Schwartz, M., Ludbrook, A., \& Glynn, M. (2020). Ryerson Open Moments. Ryerson University Press. https://pressbooks.library.ryerson.ca/openmoments/

Rosen, J. R. \& Smale, M. A. (2015, January 6). Open digital pedagogy. Hybrid Pedagogy. https://hybridpedagogy.org/open-digital-pedagogy-critical-pedagogy/

Sinkinson, C. (2018, November 18). The values of Open pedagogy. Educause Review. https://er.educause.edu/blogs/2018/11/the-values-of-open-pedagogy

Stommel, J. (2015, May 28). Open door classroom. https://www.slideshare.net/jessestommel/open-door-classroom

Schwartz, M. (n.d.). Open pedagogy. Ryerson University Press. https://pressbooks.library.ryerson.ca/openpedagogy/

Watters, A. (2014, November 15). From open to justice. https://www.slideshare.net/audreywatters/from-open-to-justice

10 Open/Technology in Education, Society, and Scholarship Association Journal: 2021, Vol. 1(2) 1-10 